\title{
Hepatitis delta infections in Toronto, Ontario
}

\author{
S. Victor Feinman. MD, FRCPC, BARnet Berris, MD, MSc, FACP, FRCPC, \\ JOHN L. Gerin, RoBERT H. PURCELl.
}

ABSTRACT: This study assessed the prevalence of hepatitis delta virus infection, the relation of this infection to the clinical and histological status and to the geographic origin of 216 patients with hepatitis B virus infection in Toronto, Ontario. Evidence of delta infection was present in 13 of the 216 patients $(6.0 \%)$. It was more common in patients with acute hepatitis $(11.1 \%)$ and with chronic hepatitis $(16.7 \%)$ than in asymptomatic carriers $(3.6 \%)$. It was not present in the three patients with hepatocellular carcinoma. The clinical course of the two patients with acute hepatitis and delta markers was similar to patients with hepatitis B alone and both made a complete recovery. Of the five patients with chronic liver disease and delta markers, three had severe chronic active hepatitis. Three of the 13 patients with delta infection were born in Canada. All three patients were intravenous drug abusers. Of the 10 patients not born in Canada, eight were immigrants from countries where delta infection is endemic. The remaining two were from West Germany and China. From this study it was concluded that, in Toronto, delta infection was more common in patients with acute and chronic hepatitis B than in asymptomatic carriers. Patients with both acute hepatitis B and delta infection had a similar clinical course to patients with acute hepatitis B alone. Patients with chronic hepatitis B and delta infection frequently had severe chronic active hepatitis. In Canadian-born patients delta infection was present in intravenous drug abusers only. Most immigrants with evidence of delta infection came from countries where delta is endemic. Can J Gastroenterol 1988; 2(4):151-5

Key Words: Clinical features, Delta infection, Prevalence, Toronto

Liver Study Unit, Department of Medicine and Research. Mount Sinai Hospital, University of Toronto, Toronto, Ontario; Division of Molecular Biology and Immunology, Georgetown University, Washington DC; and Laboratory of Infectious Diseases, National Institute of Allergy and Infectious Diseases, National Institute of Health, Bethesda, Maryland

Correspondence and reprints: Dr S. Victor Feinman, Director, Liver Study Unit, Professor of Medicine, University of Toronto, Mount Sinai Hospital, 600 University Avenue, Suite 652, Toronto, Ontario M5G 1 X5. Telephone (416) 586-5301

Received for publication June 27, 1988. Accepted August 22, 1988
$\mathrm{T}$ HE HEPATITIS DELTA VIRUS (HDV) IS an incomplete virus requiring the helper function of the hepatitis B virus (HBV) for its expression (1,2). HDV can infect a nonimmune host simultaneously with $\mathrm{HBV}$ (coinfection) or infect an hepatitis B surface antigen ( $\mathrm{HBs} \mathrm{Ag}$ ) carrier causing an acute, chronic or asymptomatic illness (superinfection). Following the introduction of sensitive methods for detecting HDV antigen and its antibodies it became apparent that HDV infections originally described in southern Italians are worldwide $(2,3)$. Endemic areas of HDV exist in the eastern Mediterranean area, the Middle East, some areas of Africa (4), among the Yucpa Indians in Venezuela (5) and in the Nauru and other islands of the western Pacific (6). In western and northern Europe and in the United States, HDV infections occur mostly in parenteral drug abusers and hemophiliacs (7-11). $\mathrm{HDV}$ infections are rare among Chinese, despite a high HBsAg carrier rate (12).

The aims of this study were to estimate the prevalence of HDV infection in patients with various types of $\mathrm{HBV}$ related liver disease in Toronto, Ontario 
TABLE 1

Geographic origin of 216 patients and type of hepatitis B virus liver disease

\begin{tabular}{lccccccc}
\hline Geographic origin & Number & AS CAR & AC HEP-B & CPH-B & CAH-B & CIRR-B & HCC-B \\
\hline Canada & 53 & 26 & 15 & 3 & 8 & 1 & 0 \\
Italy & 46 & 45 & 0 & 0 & 1 & 0 & 0 \\
Northern Europe & 28 & 22 & 2 & 1 & 1 & 2 & 0 \\
Southeast Asia & 65 & 51 & 1 & 2 & 5 & 3 & 3 \\
Eastern Mediterranean & 11 & 10 & 0 & 0 & 1 & 0 & 0 \\
$\quad$ area & 3 & 2 & 0 & 1 & 0 & 0 & 0 \\
Africa & 10 & 9 & 0 & 0 & 1 & 0 & 0 \\
Other countries & 216 & 165 & 18 & 7 & 17 & 6 & 3 \\
Total & & & & & & & \\
\hline
\end{tabular}

AS CAR Asymptomatic HBsAg carrier: AC HEP-B Acute hepatitis B: CAH-B Chronic active hepatitis B: CPH-B Chronic persistent hepatitis B: CIRR-B Cirrhosis B; HCC-B Hepatocellular carcinoma B

and to correlate the presence of HDV infection with the clinical and histological status of the patients and with their geographic origins.

\section{PATIENTS AND METHODS}

Two hundred and sixteen HBsAg positive patients were included in the study (Table 1). Of the 216, 18 had acute hepatitis $\mathrm{B}, 30$ had chronic liver disease, three patients had hepatocellular carcinoma and 165 were asymptomatic $\mathrm{HBs} \mathrm{Ag}$ carriers. Of the patients with chronic liver disease, seven had chronic persistent hepatitis, 17 chronic active hepatitis and six patients had cirrhosis.

Of the 18 patients with acute hepatitis, two were intravenous drug abusers and one of them was homosexual. All patients with chronic hepatitis, cirrhosis and hepatocellular carcinoma had liver biopsies. Histological interpretation was in accordance with the Fogerty classification (13). All the asymptomatic carriers had no clinical evidence of liver disease and had persistently normal liver function tests for at least six months.

The patients selected for study had all been referred to the Liver Study Unit at Mount Sinai Hospital, Toronto. The 165 asymptomatic carriers were selected from an $\mathrm{HBs} \mathrm{Ag}$ carrier clinic which has been following 600 carriers for many years. All patients who attended the clinic over a period of nine months were tested for antibody to HDV. These patients were evaluated every four months and have been followed for at least three years. The patients with acute and chronic liver disease were those seen in the liver clinic over a period of nine months. Patients with acute hepatitis were seen weekly and those with chronic liver disease were seen monthly. Liver biopsies were performed when clinically indicated and delta determinations were done within three to six months of the liver biopsy.

Laboratory tests: Hepatitis B surface antigen, anti-HBsAg, anti- $\mathrm{HB}$ core antigen, hepatitis $\mathrm{Be}$ antigen, anti-hepatitis $\mathrm{Be}$ and IgM anti-HBc tests were done by commercially available RIA kits (Abbott Pharmaceutical, North Chicago, Illinois).

Antidelta was measured by the commercially available antidelta RIA kit (Abbott Pharmaceutical Laboratories) and by blocking RIA in the Division of Molecular Biology and Immunology, Georgetown University. The delta antigen was measured by a blocking RIA also at Georgetown University. All samples were analyzed under code.

\section{RESULTS}

Thirteen of the 216 patients $(6.0 \%)$ were found to have antidelta in their sera. The distribution of antidelta in the various types of HBV liver disease is shown in Table 2.

\section{TABLE 2}

Prevalence of delta infection in various types of hepatitis B virus liver disease

\begin{tabular}{lccc}
\hline Diagnosis & Number & $\begin{array}{c}\text { Number with } \\
\text { delta infection }\end{array}$ & Percentage \\
\hline Acute hepatitis B & 18 & 2 & 11.1 \\
Chronic hepatitis B & 30 & 5 & \\
CPH & 7 & 1 & 14.3 \\
CAH & 17 & 3 & 17.7 \\
Cirrhosis & 6 & 1 & 16.7 \\
Hepatocellular carcinoma B & 3 & 0 & 3.6 \\
Asymptomatic carriers & 165 & 6 & 6.0 \\
Total & 216 & 13 & \\
\hline
\end{tabular}

CPH Chronic persistent hepatitis: CAH Chronic active hepatitis
Patients with acute hepatitis B: Of 18 patients $(11.1 \%)$ with acute hepatitis B two were found to have delta coinfection One had delta antigen in the serum in the first week of illness and one had high levels of antidelta in the second week of the illness. Both were Canadian-born and both were intravenous drug abusers; one was homosexual. There was no difference between the clinical presentation of the two patients who were antidelta positive and the 16 who had no evidence of HDV infection. There were no chronic sequelae in either the 16 patients with acute hepatitis B or the two patients with coincident HDV infection. The only fatal case was negative for HDV infection.

Patients with chronic liver disease: Five of the 30 patients ( $16.7 \%$ ) with chronic liver disease had evidence of delta infection. One of seven patients with chronic persistent hepatitis had antidelta in the serum; this patient had immigrated from Africa. Three of the 17 patients with chronic active hepatitis had antidelta in the serum; one was from Italy. one from Malta and one was Canadian. born. The Canadian-born patient was an intravenous drug abuser. All three patients had very severe chronic active hepatitis on liver biopsy. One of the six patients with cirrhosis had antidelta in the serum. This patient came from Germany, a country where HDV is not endemic. The patient denied intravenous drug abuse.

Asymptomatic carriers: Six of 165 carriers $(3.6 \%)$ had evidence of HDV infection. Five of the six carriers were from a group of 108 who were born in areas where HDV is endemic. Two were 
from Italy, one from Greece, one from Turkey and one from Africa. The other patient was from China, a nonendemic area. None of these patients were drug users.

\section{DISCUSSION}

The prevalence of HDV infection was $6 \%$ in the 216 patients studied. The three patients in this study who had evidence of HDV infection and who were born in Canada were all intravenous drug abusers. The majority of patients (eight of 10) with HDV infection who were born outside of Canada came from countries where HDV infection is endemic. None of these were drug abusers. A previous Canadian study also found that, where HDV infection was present, it was almost exclusively in immigrants from countries where HDV infection is endemic (14). In that study, serum antidelta was done in $326 \mathrm{HBsAg}$ positive patients. The group consisted of 216 Indochinese refugees, 46 patients with acute hepatitis, 39 blood donors and 25 patients at high risk for hepatitis (homosexuals, patients with hemophilia and drug abusers). Eight serum samples were positive for antidele (2.4\%). Seven were from Indochinese refugees whose samples were obtained on arrival in Canada and one from a homosexual male with no history of drug abuse. This was a serological survey only and the clinical and histological status of the immigrants was not mentioned in the report (14).

The high prevalence of antibody to $\mathrm{HDV}$ in the Indochinese immigrants in the aforementioned study compared to the low prevalence in the Asian group in the present study is probably due to the different areas of origin of the two groups. Almost all the Asians in the present group were from mainland China or Hong Kong rather than from Indochina. A similar finding was reported from the United States (15). Three of 70 Oriental immigrants were delta antibody positive and all were from Vietnam.

In the present study only one of the 13 patients who were positive for delta antibody was hemosexual and he was a drug abuser. Homosexuals are believed to be less susceptible to delta infection than to hepatitis B (15-17).

Two of 18 patients in this study with

TABLE 3

Comparison of prevalence of delta infection in various countries

\begin{tabular}{lccc}
\hline Country & $\begin{array}{c}\text { Asymptomatic carriers } \\
\text { percentage with delta }\end{array}$ & $\begin{array}{c}\text { Chronic liver disease } \\
\text { percentage with delta }\end{array}$ & Reference \\
\hline Italy & 6.4 & 52.3 & $(26)$ \\
France & 0.0 & 20.0 & $(6)$ \\
Germany & 0.3 & 2.7 & $(16)$ \\
Kuwait & $\mathrm{NA}$ & 66.0 & $(4)$ \\
USA & 4.3 & $\mathrm{NA}$ & $(20)$ \\
& 2.0 & 18.0 & $(17)$ \\
China & 0.0 & 2.0 & $(27)$ \\
Canada & 3.6 & 13.7 & (Present study) \\
\hline
\end{tabular}

NA Data not available

acute hepatitis B had HDV coinfection (Table 2). Both were intravenous drug abusers. Acute hepatitis due to coinfection with HDV and HBV is seen commonly in intravenous drug abusers both in countries where delta infection is endemic (7-9) as well as in countries like Canada where there is a low prevalence of HDV infection $(15,18,19)$. In endemic areas $\mathrm{HDV}$ is also common in the absence of intravenous drug abuse and in these areas transmission may be by inapparent permucosal or percutaneous routes (20).

The acute illness in the patients in this study with HBV and HDV coinfection was not more severe than in the 16 patients who had hepatitis $B$ alone and no patient in either group developed chronic hepatitis. Other studies have shown that acute coinfection with HBV and HDV does not result in chronic hepatitis more commonly than in patients who have acute hepatitis B alone $(18,21)$. The reason for this is that when HBV and HDV infection are acquired simultaneously, the HDV infection cannot outlast the HBV infection (22). In this study, the patient with fulminant hepatitis had no markers of HDV infection. However, other studies have shown a high prevalence of delta markers in patients with fulminant hepatitis $(5,23)$. This is not a universal finding. In a report from the Mayo Clinic none of eight patients with fulminant hepatitis had delta markers (15).

Chronic HDV infection is seen more commonly when HDV infection is superimposed on chronic HBV infections than when coinfection occurs. Superinfection in an $\mathrm{HBsAg}$ carrier may be subclinical or present as acute hepatitis. It frequently causes progression of liver injury and an asymptomatic carrier or one with chronic persistent hepatitis can be converted to a carrier with chronic active hepatitis and cirrhosis (24). In patients with chronic delta hepatitis, chronic active hepatitis is the most common histological lesion seen $(22,25)$. In the present study five of 30 patients with chronic hepatitis $B$ had evidence of delta infection. Three of the five had chronic active hepatitis and all three had severe disease on liver biopsy (Table 2).

There is considerable difference in the prevalence of delta infection in chronic liver disease in different parts of the world (Table 3). In countries with a low prevalence of delta infection, such as West Germany (19) and China $(12,26)$, delta infection in patients with chronic liver disease due to $\mathrm{HBV}$ is uncommon, while in endemic areas, such as Italy (27), it is common. The reasons for the difference in prevalence of HDV markers in patients with chronic active hepatitis in the reported studies are not known. They may be related to difference in frequency of drug abuse, the geographic origin of the patients or the extent of liver damage prior to the delta superinfection. It is evident that HDV superinfection of patients with chronic hepatitis B is an important contributor to chronic liver disease in some parts of the world but plays a negligible role in other areas.

The number of patients with cirrhosis and hepatocellular carcinoma in this study was too small to estimate the importance of HDV infection in their pathogenesis. In another study, coincident HDV infection did not appear to increase 
the frequency of hepatitis B related carcinoma (28).

In the asymptomatic carriers in this study, $3.6 \%$ had HDV markers. The prevalence of HDV markers in 108 patients born in countries with a high prevalence of HDV was $4.6 \%$. This approximates the prevalence in asymptomatic HBsAg carriers in an endemic area such as Italy $(6.4 \%)(28)$. In 57 patients born in countries with a low prevalence it was only $1.7 \%$.

ACKNOWLEDGEMENTS: The authors thank the Mount Sinai Research Institute for their support, Joan Freeman and Florence Strain for secretarial assistance and Thelma Berris for editorial advice.

\section{REFERENCES}

1. Rizzetto M, Canese MG, Arico S, et al. Immunofluorescence detection of new antigen-antibody system (delta-anti) delta) associated to hepatitis B virus in the liver and serum of $\mathrm{HBs} \mathrm{Ag}$ carriers. Gut 1977;18:997-1003.

2. Rizzetto M, Canese MG, Gerin JL, London WT, Sly DL, Purcell RH. Transmission of hepatitis $B$ virusassociated delta antigen in chimpanzees. J Infect Dis 1980;141: 590-602.

3. Smedile A, Lavarini C, Farci P, et al. Epidemiological patterns of infection
A low prevalence of HDV infection in asymptomatic carriers has been reported from France (6), Sweden (7), Germany (19), the USA $(4,22)$ and China $(12,29)$ (Table 3). The asymptomatic $\mathrm{HBs} A \mathrm{~g}$ carriers with delta superinfection had a similar clinical course to those without delta infection. All remained well during follow-up.

In summary, in Toronto, HBV infection was more common in patients with acute and chronic hepatitis B than in

with the hepatitis B virus-associated delta agent in Italy. Am J Epidemiol 1983; 117:223-9.

4. Rizzetto M, Hoyer BH, Purcell RH, Gerin JL. Hepatitis delta virus infection. In: Vyas GN, Dienstag JL, Hoofnagle JH, eds. Viral Hepatitis and Liver Disease. Orlando: Grune and Stratton, 1985:371-9

5. Hadler SC, De Monzon M, Ponzetto A, et al. Delta virus infection and severe hepatitis. An epidemic in the Yucpa Indians of Venezuela. Ann Intern Med 1984; 100:339-44.

6. Gust ID. The epidemiology of virus hepatitis. In: Vyas GN, Dienstag JL, Hoofnagle JH, eds. Viral Hepatitis and Liver Disease. Orlando: Grune and Stratton, 1985:415-21.

7. Hansson BG, Moestrup T, Widell A, Norenfelt E. Infection with delta agent in Sweden: Introduction of a new

\section{Les infections delta à Toronto : Prévalence et signification clinique}

Cette étude évalue la prévalence de l'hépatite virale delta, la relation entre cette infection, le statut clinique et histologique ainsi que l'origine géographique de 216 patients atteints d'hépatite virale B à Toronto. Une infection de type delta a été décelée parmi 13 patients d'un groupe de $216(6.0 \%)$. Elle était plus courante chez les patients souffrant d'hépatite aiguë (11.1\%) et d'hépatite chronique ( $16.7 \%$ ) que parmi les porteurs asymptomatiques (3.6\%). Elle était absente chez les trois patients atteints de carcinome hépatocellulaire. L'évolution clinique des deux patients atteints d'hépatite aiguë et porteurs de marqueurs delta était similaire à celle des patients atteints d'hépatite B seulement et tous deux se sont complètement rétablis. Des cinq patients atteints de maladie chronique du foie avec marqueurs delta, trois souffraient d'hépatite sévère en évolution. Trois des 13 patients souffrant d'infection delta étaient canadiens d'origine. Tous trois faisaient usage de drogue par voie intravéneuse. Des 10 sujets nés en dehors du Canada, huit provenaient de pays où l'infection delta est endémique. Les deux autres venaient de l'Allemagne de l'Ouest et de la Chine. Les auteurs concluent qu'à Toronto, l'infection delta est plus commune chez les patients souffrant d'hépatite $\mathrm{B}$ aiguë et chronique que chez les porteurs asymptomatiques. Chez les patients atteints à la fois d'hépatite aiguë $\mathrm{B}$ et d'infection delta, la maladie suivait une évolution clinique semblable à celle des seules hépatites $\mathrm{B}$ aiguës. Les patients souffrant à la fois d'hépatite chronique B et d'infection delta avaient fréquemment une hépatite évolutive chronique sévère. Parmi les patients canadiens d'origine, l'infection delta n'était présente que chez les drogués utilisant les intravéneuses. La plupart des immigrants chez qui se manifestait une infection delta venaient de pays où elle est endémique.

asymptomatic carriers. The two patients with acute hepatitis B and delta infection had a similar clinical course to the patients with hepatitis B alone and had no sequelae. In patients with chronic hepatitis B, HDV infection was frequently associated with severe chronic active hepatitis. In Canadian-born patients, it was present in intravenous drug abusers only. Most immigrants with evidence of HDV infection came from countries where HDV is endemic.

hepatitis agent. J Infect Dis

1982:146:472-8.

8. Raimondo G, Smedile A, Gallo L, Balbo A, Ponzetto A, Rizzetto M. Multicentre study of prevalence of HBV-associated delta infection and liver disease in drug addicts. Lancet 1982;i:249-51.

9. Centers for Disease Control. Fulminant hepatitis $\mathrm{B}$ among parenteral drug abusers. Kentucky, California: MMWR 1984;30:70,76-7.

10. Dentic P, Negro F, Peyretti F. Delta infection in hemophiliacs. In: Verme G, Bornino F, Rizzetto M, eds. Viral Hepatitis and Delta Infection. New York: Alan R. Liss, 1983:145-9.

11. Rizzetto M. Epidemiological patterns of infection with the hepatitis B virus-associated delta agent in Italy. Am J Epidemiol 1983;117:223-9.

12. Govindarjan S, Lee S-D, Tong MJ, Tsai Y-T, Lok J. Prevalence of delta agent among Chinese in Taiwan and Los Angeles. J Med Virol 1984;14:33-7.

13. Leevy CM, Popper H, Sherlock S. Diseases of the liver and biliary tract: Standardization of nomenclature, diagnostic criteria, and diagnostic methodology. Fogerty Inter national Centre Proceedings No. 22, National Institute of Health 1976;76-725:9-10.

14. Epidemiologic reports: Prevalence of delta agent infection in Canada. Can Med Assoc] 1986;134:375.

15. Shiels MT, Czaja AJ, Taswell HF, et al. Frequency and significance of delta antibody in acute and chronic hepatitis B. A United States experience. Gastroenterology 1985;89:1230-4.

16. Jacobson IM, Dienstag JL. The delta hepatitis agent: "Viral hepatitis, type D." Gastroenterology 1984;86:1614-7.

17. De Cock KM, Govindarajan S, Chin KP. Redecker AG. Delta hepatitis in the Los Angeles area: A report of 126 cases: Ann Intern Med 1986; 105:108-14.

18. Moestrup T, Hansson BG, Widell A, Nordenfelt E. Clinical aspects of delta infection. Br Med J (Clin Res) 1983;286:87-90.

19. Roggendorf M, Gmelin K, Zoulek G et al. Epidemiological studies on the prevalence of hepatitis delta virus 
infections in the Federal Republic of Germany. J Hepatol 1986;2:230-6.

20. Amaroso P, Giorgio A, Fico P, et al. Delta infection in the Naples area: Epidemiologic and clinical significance. JHepatol 1986;2:11-8.

21. Shattock EG, Fielding JF, Arthurs Y, Doyle GD, Kelly MG. Delta infection without increase in severity of hepatitis. Lancet 1982;ii:1286. (Letter)

22. Govindarajan S, Kamel GC, Peters RL. Prevalence of delta antibody among chronic hepatitis B virus infected patients in the Los Angeles area: Its correlation with liver biopsy diagnosis. Gastroenterology 1983:85:160-2.
23. Govindarajan S, Chin KP, Redeker AG. Peters RL. Fulminant hepatitis B viral hepatitis: Role of delta agent. Gastroenterology 1984;86:1417-20.

24. Rizzetto M, Verme G, Recchia S, et al. Chronic $\mathrm{HBs} A g$ hepatitis with intrahepatic expression of delta antigen - An active and progressive disease unresponsive to immunosuppressive treatment. Ann Intern Med 1983;98:437-41.

25. Rizzetto $M$. The delta agent. Hepatology 1983;3:729-37.

26. Rizzetto M, Purcell RH, Gerin JL, Epidemiology of $\mathrm{HBV}$-associated delta agent. Geographical distribution of anti-delta and prevalence in polytransfused $\mathrm{HBs} A g$ carriers. Lancet 1980;i: 1215-8

27. Craxi A, Raimondo G, Longo G, et al. Delta agent infection in acute hepatitis and chronic HBsAg carriers with and without liver disease. Gut 1984:25:1288-90

28. Govindarajan S, Hevia FJ, Peters RL. Prevalence of delta antigen/antibody in hepatitis B viral associated hepatocellular carcinoma. Cancer 1984;53:1692-4.

29. Xu Jian, Yan-Bo Xie. Delta infection in Chinese carriers of $\mathrm{HBsAg}$. Prog Clin Biol Res 1983;143:295-6. 


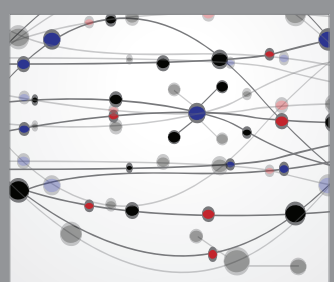

The Scientific World Journal
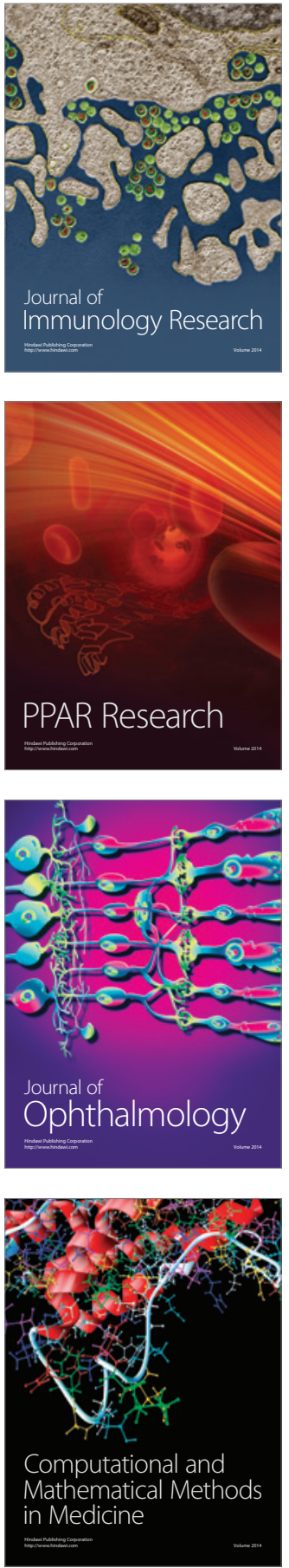

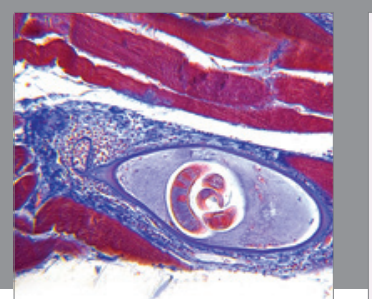

Gastroenterology Research and Practice

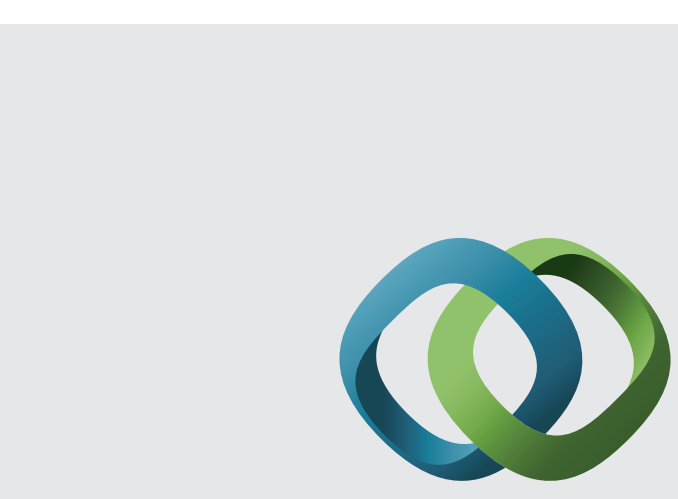

\section{Hindawi}

Submit your manuscripts at

http://www.hindawi.com
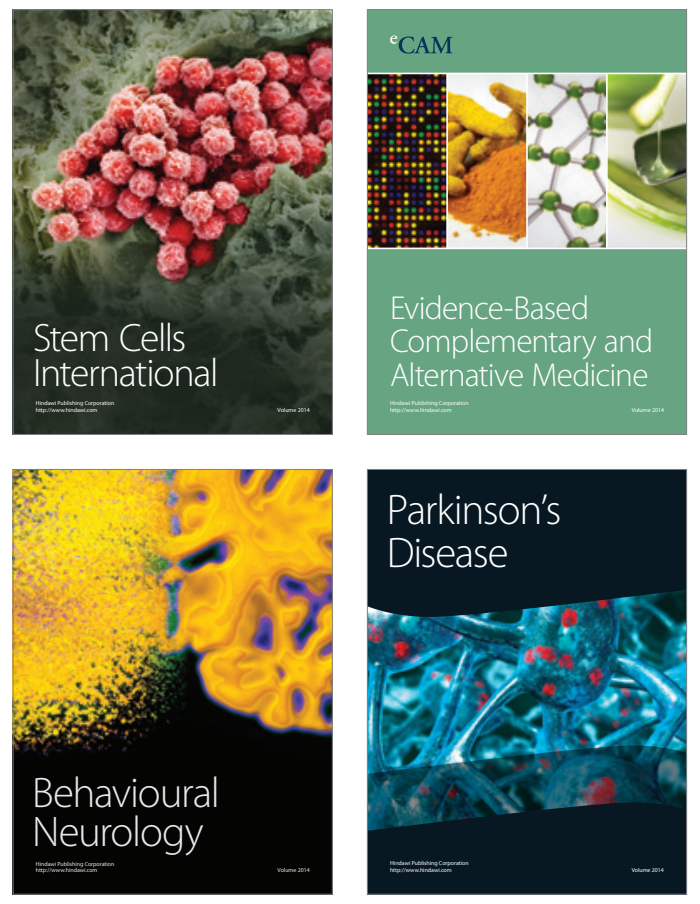
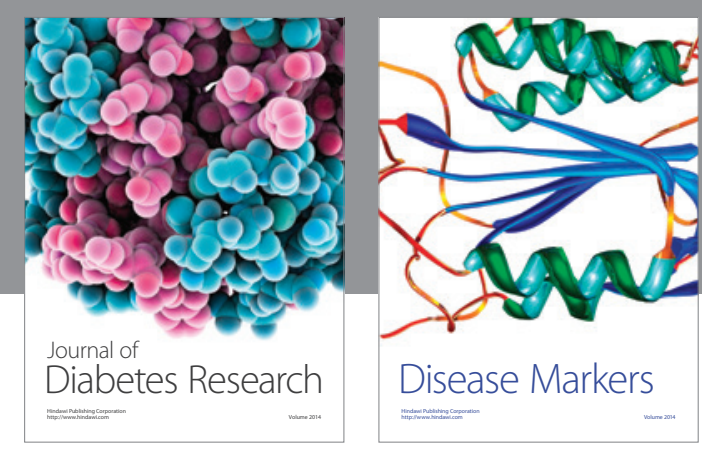

Disease Markers
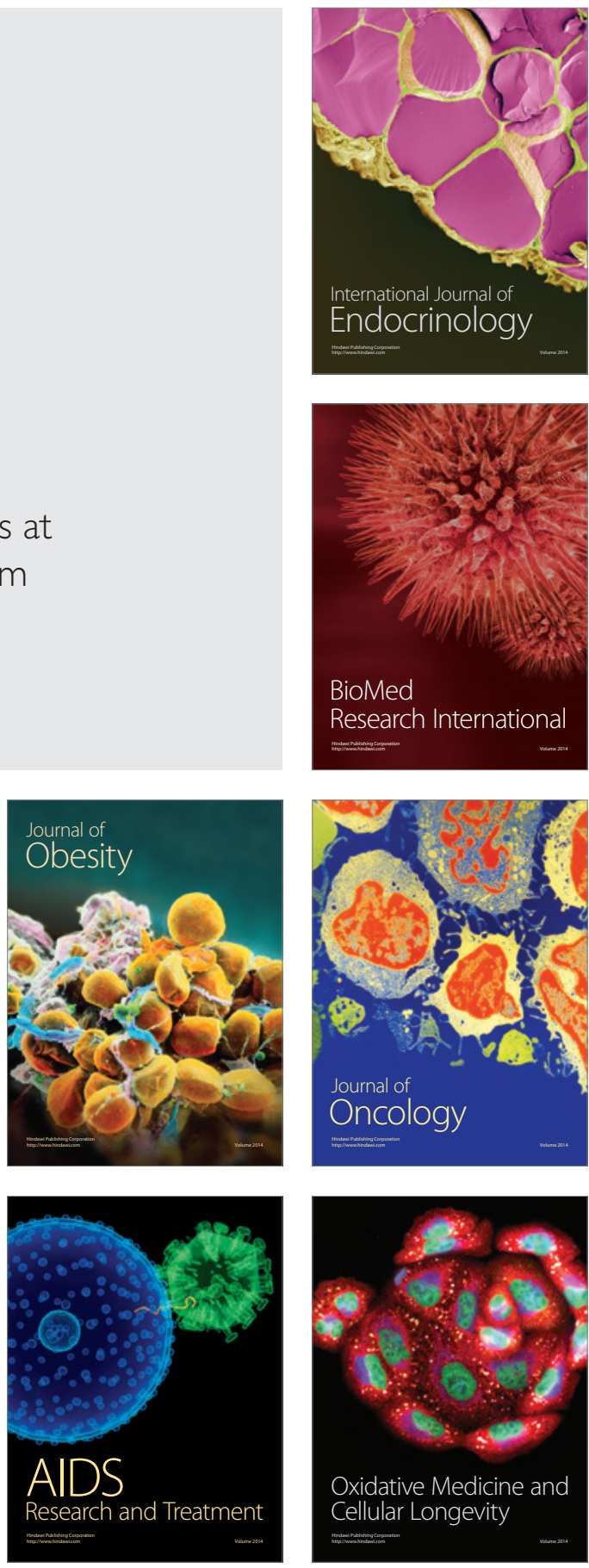